Revista Mexicana de Economía y Finanzas Nueva Época

Volumen 14 Número 3, Julio-Septiembre 2019, pp. 415-432

DOI: https://doi.org/10.21919/remef.v14i3.311

\title{
Credit Constraints and Investment in Mexico, an Empirical Test Leopoldo Gómez-Ramírez ${ }^{1}$ \\ Universidad del Norte, Colombia
}

(Primera recepción: 15/junio/2018, última recepción: 25/enero/2019, aceptado: 29/enero/2019)

\section{Abstract}

Despite the vast overhaul the Mexican economy has gone through since the 1980s, the promised high and sustained economic growth has not materialized. Scholars and policy makers are unanimous in pointing to Credit Constraints as one of the key reasons for the disappointing growth performance. The link between financial restrictions and Investment decisions, however, has not been solidly verified in the Mexican literature. This paper intends to start filling this lacuna. Using recent microeconomic, firm-level data which is reasonably nationally representative, it tests the hypothesis that Credit Constraints have reduced Investment among Mexican firms. Consistent with the general thrust of the literature, it is found that indeed financial restrictions have reduced the Investment carried out by Mexican firms. The result holds under different econometric estimations. JEL Classification: O16, G20, O54

Keywords: Contemporary Mexico, Credit Constraints, Investment

\section{Restricciones al crédito e inversión en México, una prueba empírica}

\section{Resumen}

A pesar del vasto giro económico que la economía mexicana ha experimentado desde los 1980s, el prometido alto y sostenido crecimiento no se ha materializado. Tanto los(as) académicos(as) como los(as) hacedores(as) de políticas económicas han señalado de manera unánime a las restricciones al crédito como una de las razones centrales del decepcionante desempeño del crecimiento. Sin embargo, la relación entre las restricciones financieras y las decisiones de inversión no ha sido sólidamente verificada en la literatura sobre México. Este artículo busca empezar a llenar este vacío. Usando datos recientes a nivel de firma que son razonablemente representativos a nivel nacional, prueba la hipótesis según la cual las restricciones al crédito han reducido la inversión de las empresas en México. De acuerdo con el sentido general de la literatura, se halló que en efecto las restricciones financieras han reducido de manera significativa la inversión llevada a cabo por las firmas. Los resultados se sostienen bajo diferentes estimaciones econométricas.

Clasificación JEL: O16, G20, O54

Palabras clave: México contemporáneo, restricciones al crédito, inversión

\footnotetext{
${ }^{1}$ Acknowledgements:

I thank the anonymous referees of the Revista Mexicana de Economía y Finanzas Nueva Época (The Mexican Journal of Economics and Finance) for helpful comments and suggestions. Early versions of this paper were presented at the Conference of the Association of Colombian Economics Departments, 2015, and the Seminar of the Caribbean Economics Research Institute - Universidad del Norte, Barranquilla, Colombia 2017. I thank participants in these conferences as well for their comments. Finally, I would like to thank Associate Professor Deepankar Basu and Professor Peter Skott (University of Massachusetts at Amherst) for carefully reading an commenting the whole paper (when it was still just a chapter of my Ph.D. dissertation).

*Sin fuente de financiamiento declarada para el desarrollo de la investigación
} 
Since the 1980s the Mexican economy has gone through a vast overhaul: it has been opened to foreign capital, State participation in economic affairs has been significantly diminished, protectionism has given way to trade liberalization, and, overall, the earlier import-substitution growth strategy has been displaced by an export-led one. Two pivotal moments in this vast shift were the implementation of NAFTA in 1994 and the last round of reforms which ended the state monopoly over the exploitation of oil and energy resources in 2012-2014. ${ }^{2}$ Naturally, each new round of reforms has been introduced with promises of high and sustained growth. Unfortunately, they have not materialized. Exports have increased but have not translated in growth for the economy as a whole; MorenoBrid and Ros (2009), de Souza and Gómez-Ramírez (2018). Macroeconomic stability in the form of low inflation and reductions in the fiscal deficit may have been achieved, but even these achievements should be seen in the context of severe crises in 1982-1983, 1986, 1995, and 2008-2009. Most telling, World Bank and OECD data show a strikingly low $0.6 \%$ average per capita growth rate during 1982-2014. ${ }^{3}$

Scholars and policy makers consensually accept that one of the reasons for the disappointing growth results is limited access to credit. The standard view is that firms, especially small and medium-size firms, have found it very difficult to obtain financing for productive projects since the second half of the 1990s. Indeed, Kehoe and Ruhl (2010, p. 1011) state that "The most popular set of theories for Mexico's stagnation focuses on its inefficient financial system and lack of contract enforcement." And in fact, in 2013-2014 the executive and legislative powers revised more than 30 laws governing the financial system with the stated purpose of improving access to finance; their results are still to be seen. However, although in the world economies literature the negative impact of Credit Constraints on Investment is an established point, it has not been solidly verified for the more specific contemporary Mexico case. The lacuna is certainly worrisome given the central role all sides on the larger debate on the reasons for Mexico's slow growth, summarized shortly, assign to the limited access to credit. This paper tries to start filling this lacuna. Using recent microeconomic, firm-level data which is reasonably nationally representative, it tests the hypothesis that Credit Constraints have reduced Investment in contemporary Mexico.

There are two broad variants of the explanation for Mexico's slow growth. The dominant point of view, that is, the point of view held by policy makers and scholars with influence on policies, believes that the "heart of Mexico's growth challenge" lies in the low total factor productivity; quote in Bolio et al. (2014, p. 6). The low productivity, in turn, is partially explained by the Credit Constraints faced in an inefficient financial system; Tinoco-Zermeño et al. (2014), Hanson (2010), and Kehoe and Ruhl (2010). Other scholars, however, have argued in favor of an alternative point of view. According to it, the total factor productivity slowdown is more the consequence than the cause of the slow growth, and the main reason behind the sluggishness lies in a poor Investment rate, which is in turn partially explained by the lack of bank finance for productive projects; other reasons include the low public Investment, the elimination of industrial policies, and the real exchange rate appreciation; Moreno-Brid et al. (2005), Moreno-Brid and Ros (2009) and (2010), Ros (2013) and (2015). ${ }^{4}$

Thus, whatever their larger disagreements, both sides agree Credit Constraints ha-

\footnotetext{
${ }^{2}$ At the time of the writing of the revised version of this paper (January 2019) the North American Free Trade Agreement (NAFTA) has already being renegotiated, and the new United States-Mexico-Canada Agreement (USMCA) will take its place. USMCA is expected to be effective in the second half of 2019.

${ }^{3}$ Lustig (2001) presents an early assessment of the vast economic shift Mexico has undergone. MorenoBrid and Ros (2009), Hanson (2010) and (2012), and Ros (2013) and (2015) are more recent ones.

${ }^{4}$ This is not to say, of course, that the dominant point of view does not mention low Investment as part of the explanation of the lackluster economic growth. Hanson (2012, p. 8-9) for example, actually says Credit Constraints have negatively affected productivity though the Investment channel. Likewise, the alternative approach does not completely dismiss productivity issues either.
} 
ve played an important role in Mexican sluggishness. However, and rather surprisingly, the contemporary Mexico economic literature includes very few detailed studies offering empirical evidence underpinning the claim that financial constraints have reduced Investment and/or have reduced productivity (and/or have reduced growth directly for that matter). To the best of my knowledge, there are only two such contributions: Cotler and Woodruff (2008) and Love and Sánchez (2009). Cotler and Woodruff's evidence is, however, localized and not nationally representative. Love and Sánchez's analysis is similarly unrepresentative because it is circumscribed to the rural sector while Mexico is a highly urbanized country; furthermore, the time period examined by these scholars is not very recent. This contribution intends to start filling out this literature lacuna. Using microeconomic, establishment-level data which is reasonably nationally representative and covers more recent years, this paper tests the commonly stated claim that Credit Constraints affected firm's Investment decisions. The data used are the World Bank Enterprise Surveys (hereafter WBES), carried out in Mexico for 2005 and 2009-2010 (hereafter 2010 as shorthand). The analysis is carried out separately for each period because the establishments covered in each wave of the survey are not the same. ${ }^{5}$ The main finding of this contribution is that, consistent with the general thrust of the literature, financial restrictions have indeed negatively affected Mexican firms' capital accumulation decisions.

No one paper can conclusively prove that financial constraints have had a negative effect on capital accumulation in contemporary Mexico. In other words, this contribution has limitations. Although this paper is part of a large, firmly established world economies literature, it is a more novel contribution within the more specific literature on contemporary Mexico. It is the first test of a commonly held (and certainly intuitive) statement. This novelty makes the contribution important but it also implies it is isolated. Until further research on the impact of Credit Constraints on Investment in contemporary Mexico appears, thus, its findings have to be taken with basic caution.

The contribution is organized as it follows. Section 1 presents a selected literature review. Section 2 presents the data in more detail, discusses the endogeneity issue of Credit Constraints with respect to Investment and the strategies used to address it. Section 3 presents the econometric analysis. The concluding comments section summarizes the paper and opens the discussion of policy implications.

\section{Selected Literature Review}

\subsection{World economies}

Much attention is devoted to the general topic of financial constraints in several different countries; what I call the "world economies". To begin with, many contributions have documented that, in developing economies in particular, the distribution of firms usually exhibits a "missing-middle": there are many small and medium-size firms (SMEs) alongside a few large ones, and the former are usually credit constrained; Jaramillo et al. (1996), Hericourt and Poncet (2009), Khwaja and Mian (2008), Bigsten et al. (2003), Harrison and McMillan (2003). The key concern of this missing-middle distribution finding is that, as Beck and Demirguc-Kunt write (2006, p. 2932), many scholars take as a "premise" that small- to middle-size firms "are the engine of economic development."

In the world economies literature many papers have examined limited access to credit at the firm level. While some of them have inquired about their impact on key economic variables, like employment and Investment, others have focused more on establishing the existence of such Credit Constraints and/or in examining their underlying reasons. Banerjee and Duflo (2014), for example, offer empirical evidence suggesting that many

\footnotetext{
${ }^{5}$ Enterprise Surveys (http://www.enterprisesurveys.org), The World Bank. The WBES were carried out in 2006 and 2010-2011 with most of the questions referring to the last fiscal year, which in Mexico is the same as the calendar year. The majority of the establishments in the 2010-2011 WBES were interviewed in 2011: 1127 out of 1480.
} 
relatively large Indian firms have been severely credit constrained. Hericourt and Poncet (2009) finds that Chinese private firms have been credit constrained while public ones have not. Khwaja and Mian (2008) examines if Pakistani firms' financing saw a reduction after the 1998 nuclear tests, which in turn negatively affected the supply of loans, finding that small firms were unable to smooth the loans crunch through the use of alternative sources of finance. Harrison and McMillan (2003) finds that Ivory Coast enterprises faced more acute Credit Constraints than foreign ones. Bigsten et al. (2003) delves into a wider range of African countries, namely, Cameroon, Ghana, Kenya, Zimbabwe, Burundi, and the Ivory Coast, finding that the larger and/or the more profitable an enterprise is the less likely is it is credit constrained. Jaramillo et al. (1996) finds that in Ecuador smaller/younger firms faced more acute Credit Constraints than larger/older ones.

In the world economies literature there are also contributions which, while maintaining the firm-level approach, investigate the impact of credit restrictions on key economic variables, like Investment and employment, Fazzari et al. (1988) is a seminal paper, which sparked large influence not only because of its findings but also because of its empirical methodology (to be discussed more in section 2). Its findings are that United States (U.S.) manufacturing firms were credit constrained and that those constraints negatively impacted Investment. Hu and Schiantarelly (1998) also finds that U.S. manufacturing firms were credit constrained. Chodorow-Reich (2014) examines the role of U.S. firms' access to credit on their employment decisions, finding that the credit crunch which happened after the 2008 crisis reduced employment but only among SMEs. With respect to other than U.S. enterprises, Galindo et al. (2007) examine the effect of financial liberalization on the allocation of Investment in several developing economies which underwent financial liberalization measures over the last several years: Argentina, Brazil, Chile, India, Indonesia, Korea, Malaysia, Mexico, Pakistan, Philippines, Taiwan, and Thailand. It finds that "financial liberalization in the majority of cases leads to an improvement in resource allocation, although there are interesting exceptions" (p. 564).

To finish this "world economies" selected literature review it is worth mentioning two very influential papers which, unlike the contributions so far mentioned, address the role of Credit Constraints on growth with a "macro", cross country regressions perspective, and not with a "micro" or firm-level one. First, King and Levine (1993), which finds that financial development is "strongly and robustly correlated with" growth (p. 734). Second, Aghion et al. (2005), which finds "strong evidence ... for the general proposition that whether or not a country converges to the frontier growth rate depends on its level of financial development" (p. 189). Interestingly, the estimates of these papers also suggest a "step" positive relationship between financial development and growth.

\subsection{Mexico's literature}

When passing to the literature on Credit Constraints in contemporary Mexico, we find no dearth of papers either. What we found, however, is that instead of examining their possible impact on key economic variables, in this literature there are many more contributions trying to explain the reasons of the credit crunch. The central question is why lenders, especially the banks, lend so little for productive purposes, especially since the second half of the 1990s; even while credit for consumption and housing has in fact increased since then. Bergoeing et al. (2002) compares Chile's and Mexico's bankruptcy laws. Haber (2005), and Haber et al. (2008) focuses on the banks' privatization process. Mántey de Anguiano (2007) points out that banks make good enough profits by buying government bonds and engaging in the derivatives market. Haber (2009) finds evidence suggesting that banks lend too little because of the oligopolistic nature of their market and because of the difficulties the lenders have in seizing assets from borrowers if they default. Haber and Mussachio (2012) presents a detailed study of the impact of foreign banks' entry into Mexico. Tinoco-Zermeño et al. (2014) examines the effect of inflation 
on the low bank credit rates. Chavarín (2015) finds no evidence in favor of the thesis that the low lending comes from borrowers not paying back on time.

Contributions focusing on the distributional dimension of the Mexican credit crunch could be found too. These papers offer evidence of and/or explanations for why SMEs are more credit constrained than larger ones; Garrido and Prior (2007), Lecuona (2009), Clavellina (2013). Other contributions have focused on the impact of Credit Constraints on poverty and on informality; Niño-Zarazua (2013), Carreón et al. (2007). Interestingly, in this literature Bruhn and Love (2014) not only examines the impact of easing Credit Constraints on poverty but also delves into the gender dimension of the issue. It is possible to even find contributions on the possible effects of limited access to credit on migration; Aroca and Maloney (2005), Angelucci (2015).

Some few contributions have examined the possible effects of the credit crunch on other economic variables. McKenzie and Woodruff (2008) investigates the effects of easing capital constraints on firms' profits, finding a positive and significant effect. Inspired in the Mexican economy, Skott and Gómez-Ramírez (2018) examines from a theoretical perspective the implications for employment and distribution of a relaxation of the financial constraints in the context of a dual economy (with a large informal sector with hidden underemployment). It finds that, in the absence of supplementary policies, the relaxation of the financial restrictions may reduce the share of the formal sector, increase inequality and underemployment.

Now, given it would sustain the view customarily held among policy makers, one would expect a solid body of empirical literature confirming that limited access to credit has negatively affected total factor productivity. Nevertheless, such a body of literature could not be found; Villalpando (2014) is an exception, as it does try to offer evidence supporting the claim that there has been a negative effect of financial restrictions on productivity. Perhaps the reason of this worrying gap found in the literature is related with the difficulty of obtaining good quality data on Investment, especially at the firm level, which could reasonably be considered nationally representative too. In any case it is still rather disappointing to find that policy makers do not seem to have solid empirical evidence underpinning their standard point of view.

Among scholars adhering to the alternative point of view on the "Mexican morass", empirical evidence confirming that Credit Constraints have deterred capital accumulation are also difficult to find. Again, data limitations may explain this lacuna but it is still worrying. Scattered papers offering evidence in favor of this negative relationship but covering time periods prior to the second half of the 1990s are found. Gelos and Werner (2002) examines manufacturing firms from 1984 to 1994. Sánchez (2001) also investigates manufacturing establishments for 1984-1999. Castañeda (2003) goes over the time period before and after the 1995 crisis. Ramírez (1994) and Warman and Thirwall (1994) both address the role of financial constraints on Investment only incidentally, that is, including financial restrictions only as control variables of their regressions; furthermore, they cover a period before the mid-1990s, and the Credit Constraints for productive projects in Mexico have become harsher after it. In any case it may be worth mentioning that both papers obtained negative and significant coefficients on the financial restrictions variable.

There are only a couple of contributions which cover more recent years and in which the effect of financial constraints on Investment is of primary interest. The first is Cotler and Woodruff (2008). It examines the impact of micro-lending on physical capital Investment, among several "measures of the firm's performance." Overall, the paper finding is a positive and significant relationship between obtaining a loan and Investment in fixed assets. The data for this contribution is quasi-experimental, that is, it consists of both a "treated" and a "control" group of enterprises similar in many respects. The use of this type of quasiexperimental data has clear strengths. They come at a cost, tough, which is, quoting Beck and Demirgunt-Kunt (2008 p. 390) "whether the results found in one specific geographic or 
socioeconomic environment can easily be applied to a different environment." Cotler and Woodruff investigation is circumscribed to small retailers located in two neighborhoods of the suburban area of Mexico City. Mexico is a very large, highly uneven, and complex country. Results obtained from small retailers of two neighborhoods of Mexico City are hardly nationally representative. Cotler and Woodruff are aware of the scope of their findings (p. 848).

The second is Love and Sánchez (2009). These scholars find evidence suggesting that easing Credit Constraints would increase both the number of agents investing and their levels of Investment. Their findings, however, are not about a very recent time period, as they used surveys from 1999 and 2001. Most importantly, this contribution is circumscribed to the rural Mexican sector. Contemporary Mexico is, however, a highly urbanized country; at least since the 1980s some $75 \%$ of its inhabitants have been living in urban areas.

It turns out, thus, that this paper presents the first test of the effect of Credit Constraints on Investment using good quality firm-level data that are both recent and reasonably nationally representative. Given the importance of this purported link in scholarly literature and policy discussions, this empirical test makes an important contribution.

\section{Data, Measures of Investment and Credit Constraints, and En- dogeneity Issues}

This section is divided into three subsections. The first describes in more detail the WBES data. The second describes the measures used for the key variables of our analysis. The third discusses the thorny issue of the highly likely endogeneity of Credit Constraints with respect to Investment decisions.

\subsection{Data: The World Bank Enterprise Surveys for Mexico}

The World Bank Enterprise Surveys offer a rich source of good quality information on Mexican establishments. ${ }^{6}$ Each survey interviewed 1480 establishments, gathering information on fifteen broad topics. First, the general characteristics of the establishments, including ownership, legal status, and size. Second, the infrastructure and services they have (or do not have) access to, like electricity, water, internet, etc. Third, the quantity and nature of their sales, including national/international and main/secondary products/services. Fourth, the quantity and nature of their demand for inputs. Fifth, the degree of competition they face. Sixth, the innovation measures they have (or not) introduced. Seventh, their capacity utilization. Eighth, their land tenure. Ninth, their interest in being and/or pressures to be environmentally responsible. Tenth, their relationship with the courts. Eleventh, the ways crime has affected their operations. Twelfth, their relationship with the government, including if they have bribed officials. Thirteenth, their financial situation. Fourteenth, their labor force: number, permanent or temporary, and their education levels. And, fifteenth, the self-perceived main constraints on their operation. It should be said that the World Bank WBES team has been doing a high quality job in collecting these surveys worldwide, and Mexico is not the exception.

An important strength of this data set, and therefore of the analysis in this paper, is that it is reasonable to consider it nationally representative. Table 1 presents key indicators with evidence supporting this assertion. It shows the number of establishments which were surveyed according to their geographic location, sector, and size; the latter is measured with the number of full time permanent workers, following what the Quarterly

\footnotetext{
${ }^{6}$ Both the 2006 and the 2010-2011 WBES are divided into three surveys: one for manufactures, one for services, and one for "others." Each of them is slightly different.

In the WBES terminology an "establishment" is a single site and a "firm" may have more than one establishment.
} 
Survey on Enterprises Financing Sources carried out by the Mexican Central Bank does. ${ }^{7}$ The enterprises surveyed are distributed all across the country (with the exception of the Southeast, which we'll discuss shortly), they belong to different economic sectors (many concentrate in manufactures, but this sector is itself subdivided into more than a dozen different subsectors), and they are of several different sizes (in terms of how many full-time permanent workers they hire).

Table 1. Indicators suggesting WBES data are nationally representative

\begin{tabular}{|l|c|c|}
\hline & $\mathbf{2 0 0 5}$ & $\mathbf{2 0 1 0}$ \\
\hline Region (state): & $482(32.57 \%)$ & $311(21.01 \%)$ \\
Eexico city & $478(32.30 \%)$ & $417(28.18 \%)$ \\
Veracruz) & $201(13.58 \%)$ & $449(30.34 \%)$ \\
West Center (Guanajuato, Jalisco) & $319(21.55)$ & $303(20.47 \%)$ \\
North (Nuevo León, Coahuila, & $1122(75.8 \%)$ & $1152(77.84 \%)$ \\
Chihuahua) & $237(16 \%)$ & $125(8.45 \%)$ \\
\hline Sector: & $121(8.18 \%)$ & $203(13.72 \%)$ \\
Manufacturing & & \\
Services & $12(0.81 \%)$ & $34(2.30 \%)$ \\
Other & $736(49.73 \%)$ & $478(32.29 \%)$ \\
\hline Size (measured with the number of full- & $439(29.66 \%)$ & $429(28.98 \%)$ \\
time permanent workers): & $293(19.8 \%)$ & $475(32.09 \%)$ \\
Less than 5 workers & & \\
Between 5 and 19 workers & & \\
Between 20 and 99 workers & & \\
100 or more workers & &
\end{tabular}

Source: Author's calculations based on Enterprise Surveys (http://www.enterprisesurveys.org), The World Bank

It should be mentioned, however, that there are two important features of the Mexican economy which are missed in the WBES. First, with very few exceptions these surveys gathered information on formally registered establishments with more than 5 workers while it is well known that a large proportion of businesses in Mexico are informal; INEGI (2004) and (2011), Bolio et al. (2014). However, the absence of informal establishments in the WBES data set could actually strengthen the thesis that Credit Constraints have negatively affected firms' real Investment decisions. If it is shown that Investment by large, formal firms has been negatively affected by Credit Constraints then it does not seem unreasonable at all to also believe that the negative effect on small, informal firms has actually been stronger, as the latter almost certainly have less access to credit than the former; indeed, the lack of access to credit faced by small informal firms is one of the reasons for which they remain small and informal. Second, the WBES did not interview firms located in the Southeast of the country, which is also well known to be poorer and more backwards than the rest of the regions; Ros (2015). But for analogous reasons to the ones related with missing data on small informal firms, missing information on Mexico's Southeast could actually strengthen the findings of this paper. In short, the selection bias in the data set - the overweighting of large formal sector firms, not located in the most backwards region of the country- very likely reinforces the conclusion that Credit Constraints have negatively affected firms' real Investment decisions in contemporary Mexico.

\footnotetext{
${ }^{7}$ Quarterly Survey on Enterprises Financing Sources carried out by Mexico's Central Bank; http://www.banxico.org.mx/dyn/informacion-para-la-prensa/comunicados/sectorfinanciero/financiamiento-empresas/index.html
} 


\subsection{Investment and Credit Constraints}

The measure of Investment used in this paper is a binary variable indicating whether in the last year the firm bought fixed assets such as machinery, vehicles, equipment, land or buildings (Investment). ${ }^{8}$ The independent variable of primary interest, our measure of Credit Constraints, is based on the categorical measure of financial restrictions proposed by Kuntchev et al. (2013) (Credit Constraints). It is appropriate for our analysis for two reasons. First, and very importantly, because it is built upon precisely the information obtained by the World Bank Enterprise Surveys. Second, because, quoting Kuntchev et al. (2013, p.3), it provides an innovative way of measuring credit-constrained firms based both on their usage of and ability to obtain new credit. This is an important contribution of the literature since most papers ... either look only at usage of credit, as opposed to access, or focus on self-reported obstacles based on perceptions instead of objective on the experience of the firm.

The conceptual essence of this measure of financial restrictions is that an establishment is credit constrained if it wanted to have external finance but for some reason it could not get it (in which case Credit Constraints equals 1), and it is not credit constrained if it either did not want to obtain external funding or did obtain it (in which case Credit Constraints equals 0$).^{9}$

Two features of our variable Credit Constraints are important to be highlighted. The first is it directly allows us to know whether a firm was credit constrained or not. This is important because, in turn, it allows us to depart from the widely followed but challenged methodology Fazzari et al. (1988) sparked. In it, the existence of Credit Constraints is indirectly discovered, so to speak, in the following way. The whole sample of firms is divided, using a priori criterions (like retained earnings), into subsamples according to the degree of financial restrictions each group is supposed to face. Then regressions of Investments on cash flows and other control variables are carried out for each such subsample. Reasoning that in a world with perfect financial markets (a-lá Modigliani and Miller (1958)) their liquidity levels should have no effect on firms' Investment decisions, if the coefficients of the cash flows variables are significant and increasing with the degree of financial exclusion, then it could be established that there are Credit Constraints. This methodology has in essence been followed, with extensions and minor modifications, by many in the world economies literature; Jaramillo et al. (1996), Hu and Schiantarelly (1998), Harrison and McMillan (2003), Almeida and Campello (2007), Hericourt and Poncet (2009); and for the Mexican case by Gelos and Werner (2002), Sánchez (2001), Castañeda (2003). However, it has been criticized precisely for a priori partitioning the sample into groups of firms according to their degree of Credit Constraints; Kaplan and Zingales (1997). It is beyond the scope of this paper to evaluate this debate but it suffices to mention that here we don't need to deal with it because our Credit Constraints variable directly captures if a firm was financially restricted or not; in this respect, this paper is similar to Bigsten et al. (2003).

The second is that Credit Constraints allows us to confidently say our findings are about "real" effects of Credit Constraints. In other words, it allows us to establish that firms financially excluded for some reason were not able to find alternative sources of financing. Indeed, the literature has often stressed that, in order to establish that some form of credit crunch transmits into firms' "real" outcomes, it should be established that

\footnotetext{
${ }^{8} \mathrm{I}$ am aware that having a continuous variable with the amount of Investment would have much enriched the analysis. And the WBES actually asked firms managers about the amount their firms invested. Unfortunately, very few firms responded accurately.

${ }^{9}$ Kuntchev et al. (2013) measure classifies firms in four categories: "not", "maybe", "partially", or "fully credit constrained", and our measure considers the first two as "not credit constrained" and the other two as "credit constrained." But both measures capture the same essence of the concept of Credit Constraints just described.
} 
the firm could not find alternative financing sources; Kashyap and Stein (2000), Khwaja and Mian (2008), Chodorow-Reich (2014). In this paper, we can be sure of it because, when asking if the establishment received credit or not, the WBES referred to any financing source: private commercial banks, state-owned banks and/or government agencies, nonbank financial institutions, credit from suppliers and advances from customers, and "other" ("moneylenders, friends, relatives, bonds, etc.").

Table 2 presents descriptive statistics of Investment and Credit Constraints. In both rounds of the surveys, around $30 \%$ of establishments were credit constrained. That this number is not as large as other surveys show (like the already mentioned above Quarterly Survey on Enterprises Financing Sources carried out by Mexico's Central Bank) is not surprising, given that the firms surveyed in the WBES are not informal, small ones, and actually many of them made handsome profits. With respect to capital accumulation decisions, in the 2005 survey $28.5 \%$ of establishments reported that they invested. In $201053.5 \%$ accumulated physical capital. This increase is not surprising since larger firms were surveyed in 2010 than in 2005 (see Table 1). More detailed examination (not shown) of Investment behavior by enterprise size showed that larger ones invested more than smaller ones in both rounds of the survey, not surprisingly.

Table 2. Investment and Credit Constraints

\begin{tabular}{|l|c|c|}
\hline \multirow{2}{*}{ Invested } & $\mathbf{2 0 0 5}$ & $\mathbf{2 0 1 0}$ \\
\hline Not Invested & $422(28.5 \%)$ & $792(53.5 \%)$ \\
\cline { 2 - 3 } Credit Constrained & $1054(71.2 \%)$ & $686(46.3 \%)$ \\
\cline { 2 - 3 } Not Credit Constrained & $438(29.5 \%)$ & $399(26.9 \%)$ \\
\cline { 2 - 3 } & $1019(68.8 \%)$ & $1021(68.9 \%)$ \\
\hline
\end{tabular}

Author's calculations based on Enterprise Surveys (http://www.enterprisesurveys.org), The World Bank

\subsection{Endogeneity Issues}

It is highly likely that Investment decisions affect the credit situation of the establishment, that is, it is highly likely that Credit Constraints are not exogenous but are endogenous with respect to physical capital accumulation decisions. Literature examining the effects of financial restrictions on innovation does assume endogeneity of the financial situation with respect to the innovation decisions; Savignac (2008), Gorodnichenko and Schnitzer (2013). Since innovation is actually one form of Investment, it is straightforward to believe the issue extends for physical capital Investment too. Furthermore, the intuitive argument explaining this endogeneity, which is the following, is compelling. An establishment decides to invest. For financing such Investment, it could use internal or external funds. Due to the difficulties of enforcing loan contracts and due to asymmetric information issues, using external funds would very likely be more expensive than using internal ones. Thus, it is likely the firm would rely on internal funds to the extent possible. However, using up internal funds on Investment increases the likelihood of facing Credit Constraints because the firm would then lack collateral.

Both because this argument is intuitively compelling and because the literature usually accepts there is endogeneity, in this paper we, too, accept that Credit Constraints are endogenous with respect to Investment. Accepting it, however, leaves us with the need to address an econometric issue certainly difficult to address; indeed, it is fair to say that the core concern of a large amount of modern econometrics is about how to deal with endogeneity.

Addressing this issue when the dependent variable is binary has its particular difficulties, and in fact our dependent variable of primary interest (Investment) is binary. Lewbel, Dong and Yang (2012) discuss four types of convenient estimators which could be used in this context; first, two-stage linear probability models (LPMs); second, maximum likelihood estimators, like a bivariate probit system of equations; third, control function 
estimators, like Stata's ivprobit, which according to the same Lewbel and coauthors (p. 818) "despite its name... is actually a control function estimator, not an instrumental variables estimator"; and fourth, the "special regressor" method proposed by the same scholars in different contributions; Lewbel (2000), Lewbel et al. (2012), Dong and Lewbel (2015). In this paper, the analysis is carried out, first, with bivariate probit estimation, and, second, with the special regressor method. But it is worth explaining in some more detail the reason for choosing these two.

Using two-stage LPM was discarded for the well-known problems of LPMs in general; to begin with, it may not yield estimates which actually fall in the range $\beta \epsilon[0,1] .{ }^{10}$ As a potential solution to this problem, ivprobit is commonly found in the literature. In fact, however, carrying out an ivprobit when the independent variable of key interest is not continuous is mistaken. That an ivprobit would not generally yield consistent estimators when the endogenous regressor is binary, discrete, or censored is a point established by Lewbel and coauthors, and indeed the Stata reference manual (version 14) clearly states that ivprobit is "not appropriate" when the endogenous regressor is binary. ${ }^{11}$ Given that our variable Credit Constraints is binary, this estimation method was therefore discarded too. Now, highly regarded econometricians have established that estimating a bivariate probit in the context of both binary dependent and independent variables with the latter being endogenous is an appropriate strategy; Greene (1996) and (2012). Furthermore, several literature contributions facing this binary-variables-with-endogeneous-regressor problem have actually estimated a bivariate probit; Evans and Schwab (1995); Greene (1998), Christofides et al. (1997), Ploetscher and Rotmman (2002), Savignac (2008). And indeed Lewbel and coauthors do not simply discredit the use of bivariate probit but instead highlight the other requirements needed for its proper application. As one would expect, however, estimating a bivariate probit is not entirely a free lunch. The main difficulty is that, as Lewbel and colleagues highlight, to yield consistent estimators it requires that the equation for the endogenous regressor is not just any equation but the right one, one which does not omit any relevant instruments (IV).

This mentioning of instruments leads us to the very important question of what variables are appropriate IV for Credit Constraints. We know they have to affect the firm's financial restrictions but without having an unmediated effect on its Investment decisions. In other words, they have to influence firms' Investment decisions only through the channel of affecting its credit situation. It is certainly not that easy to find such variables. Fortunately, Gorodnichenko and Schnitzer's (2013) contribution was very useful for us here. In their study of the effects of Credit Constraints on innovation decisions, these scholars propose to use, as IV for the firm's Credit Constraints, "unexpected shocks" to its cash flows; like goods stolen or lost while in transit to their final destination, among others. The key reason for which these shocks are considered as proper IV is that, if they are truly unexpected, then they do affect the firm's financial situation but cannot directly affect its Investment decisions. Fortunately for us, the WBES gathered information on variables that can be deemed to be unexpected shocks to the firm's cash flows. These are the IV used in this paper, described in more detail in section 3.

The equation for Credit Constraints in the bivariate probit estimation, thus, include these unexpected shocks as IV. As we just mentioned, however, Lewbel and coauthors have established that, for it to yield consistent estimators, no relevant instrument should be missed. For these and other reasons, these scholars propose the use of what they call the "special regressor method." It only requires the existence of the special regressor V with certain properties to yield consistent estimates even if not all the relevant IV for the endogenous regressor are included. In other words, with this method all what we need is any proper instrument and the special regressor V. In turn, the properties of $\mathrm{V}$

\footnotetext{
${ }^{10}$ Lewbel et al. (2012) discusses several other flaws of LPMs.

${ }^{11}$ See https://www.stata.com/manuals14/rivprobit.pdf, p. 1.
} 
which make it special are that it is continuously distributed, it has a large support, it is independent, and it is positively related with the dependent variable. Given that among our independent variables we do have some which satisfy these properties, it was rather natural to carry out the analysis with this special method too, and therefore we did it. Doing so is, quoting Lewbel et al. (2012, pp. 828) "useful, at least in providing robustness checks of results against alternative, more standard estimators."

\section{Econometrics}

Our first estimation is of the bivariate probit of the following equations:

1. Investment $^{*}=X_{1} \beta_{1}+($ CreditConstraints $) \gamma+\varepsilon_{1}$; Investment 1 if Investment ${ }^{*}>0$, 0 otherwise,

2. CreditConstraints ${ }^{*}=X_{\mathbf{2}} \beta_{\mathbf{2}}+\varepsilon_{2}$; CreditConstraints $=1$ if CreditConstraints ${ }^{*}>0,0$ otherwise. $^{12}$

in which $\varepsilon_{1}$ and $\varepsilon_{2}$ are bivariate normal with mean zero, unit variance and $\rho=$ $\operatorname{Corr}\left(\varepsilon_{1}, \varepsilon_{2}\right)$. The main interest is in $\gamma$, and in the implied "marginal effect" of Credit Constraints on Investment. If $\rho=0$ the model consists of independent probit equations, which can be estimated separately. Alternatively said, if $\rho \neq 0$ probit estimation of (1) is inconsistent for $\beta_{1}$ and $\gamma$; Greene (2012, pp 741-742), Woolridge (2002, p. 477). There are, of course, variables other than Credit Constraints influencing Investment decisions, and they are included in the matrix of control variables $X_{1} \cdot{ }^{13}$ For its part, the matrix $X_{2}$ has the IV for the endogenous regressor Credit Constraints. Recalling the remarks of Lewbel and coauthors according to which dropping relevant variables in this equation usually yields inconsistent estimates, different specifications with more and fewer instruments in $X_{2}$ were used. In Table 4 we present the estimates obtained with the shortest specifications but the results were quantitatively very similar and highly statistically significant too with all the other specifications; the .do files are available by request. It is important to mention, by the way, that all the econometric analysis of this paper was carried out with Stata software.

The "unexpected shocks" to the firm's cash flows included as IVs in $X_{2}$ are, for year 2005 , the losses in sales due to robbery, breakage or spoilage, either in the place of operations or while shipping products (Lostsales); and if crime was a severe obstacle for the firm's operation (Obstcrime). For year 2010 the unexpected shocks included are the informal payments given to officials to "get things done" with regards to customs, taxes, licenses, regulations, services, etcetera (Infpayments); and Obstcrime. Naturally, we would have preferred to symmetrically include the three IV in both years. Doing so, however,

\footnotetext{
${ }^{12}$ In the literature there are contributions that, for some reason, estimate a recursive bivariate probit instead of a bivariate one; Evans and Schwab (1995); Greene (1998). In our case, it means Investment is not included in the Credit Constraints equation, that is, it is not in the matrix $X_{\mathbf{2}}$. These recursive bivariate probits were estimated here too. The results for both 2005 and 2010 were virtually the same.

${ }^{13}$ The variables included in $X_{1}$ are the following. First, the total value of sales; as a robustness check, instead of sales the total value of profits was used, too. Second, the size of the establishment, measured by the number of full-time workers. Third, and very related with the second, if the establishment was part of a larger firm or not. Fourth, the percentage of sales sold in domestic markets. This variable is introduced in order to capture the effect of exposure to foreign markets. Fifth, the establishment's capacity utilization, which can be seen as a proxy for aggregate demand. Sixth, the number of competitors the establishment faced in its main market. Seventh, the age of the firm, measured with the number of years it has been operating. Eighth, two measures capturing if the establishment innovated in the last three years, namely, if it introduced a new product or service and if introduced a new method or process of production. Ninth, if the firm spent money on private security (given the high levels of insecurity in contemporary Mexico it was necessary to control for it). Tenth, measures of the two self-declared most important obstacles to the establishment's operation. In 2005 they were the competition of other informal firms and macroeconomic instability, and in 2010 they were the competition of other informal firms and the tax rates.
} 
was not possible because of data limitations: it would have implied losing around $80 \%$ of the observations.

Table 3 presents the key results of the estimations of the bivariate probit system (1)-(2). To highlight that addressing the endogeneity issue does make a difference in the analysis, the simple probit estimations are also shown. The bivariate probit column for 2005 presents the shortest specification with only Lostsales as IV, and the column for 2010 presents this year's shortest with only Infpayments as IV. As I just mentioned, however, the results with all the other longer specifications were quantitatively very similar and exhibited the same very high levels of statistical significance. Now, as it is well known, in any probit model (univariate or bivariate) we are usually interested not only in the directly estimated coefficient of the binary independent variable of interest but also in its implied "marginal effect". Intuitively, the marginal effect of $\mathrm{X}$ on $\mathrm{Y}$ is an estimation of how much more likely is the outcome of $\mathrm{Y}$ occurs if the outcome $\mathrm{X}$ occurs, as compared with the case in which the outcome of X didn't occur; and all else equal, of course. In concrete, in this paper the central interest is in the marginal effect of Credit Constraints on Investment, which intuitively is the estimation of how much more likely is some firm does not invest if it is credit constrained, as compared with the case in which it were not credit constrained, all else equal. As it is well known, in order to estimate this marginal effect of the independent variable of primary interest it is necessary to posit values of all the other explanatory variables. The bivariate probit literature usually uses their means; Greene (1996), (1998) and (2012), Christofides et al. (1997). Thus, the marginal effects of Credit Constraints on Investment shown in Table 3 were calculated following this custom.

Table 3. Bivariate Probit Estimations

\begin{tabular}{|c|c|c|c|c|}
\hline \multicolumn{5}{|c|}{ Dependent Variable: Investment } \\
\hline & \multicolumn{2}{|c|}{2005} & \multicolumn{2}{|c|}{2010} \\
\hline & Probit & $\begin{array}{l}\text { Bivariate } \\
\text { Probit }\end{array}$ & Probit & $\begin{array}{l}\text { Bivariate } \\
\text { Probit }\end{array}$ \\
\hline $\begin{array}{l}\text { Independent Variable: } \\
\text { Credit Constraints }\end{array}$ & $\begin{array}{c}-.2747441^{* *} \\
(.1116022)\end{array}$ & $\begin{array}{c}-1.552551^{* * *} \\
(.0691767)\end{array}$ & $\begin{array}{c}-.2637807^{* * * *} \\
(.095205)\end{array}$ & $\begin{array}{c}-1.595132^{* * *} \\
(.0616775)\end{array}$ \\
\hline $\begin{array}{l}\text { Marginal Effect of } \\
\text { Credit Constraints on } \\
\text { Investment }\end{array}$ & $\begin{array}{c}-.0786975 * * \\
(.0315775)\end{array}$ & $\begin{array}{c}-.4708525 * * * \\
(.015268)\end{array}$ & $\begin{array}{c}-.0902337^{* * * *} \\
(.0321764)\end{array}$ & $\begin{array}{c}-.4785846^{* * *} \\
\quad(.0118388)\end{array}$ \\
\hline Observations & 840 & 840 & 957 & 884 \\
\hline $\begin{array}{l}\text { Wald test chi statistic } \\
\text { under the null of } \backslash \mathrm{rho}=0\end{array}$ & & $99.2632^{* * *}$ & & $124.728^{* * *}$ \\
\hline
\end{tabular}

$5 \%$, and $1 \%$ level, respectively

Three pieces of information of Table 4 are important to be highlighted. First, and most importantly, in both 2005 and 2010 it is estimated that financial restrictions negatively affected Investment decisions at high levels of statistical significance. In 2005, it is estimated that, if credit constrained, the likelihood an establishment would invest is reduced by $47 \%$, at the $1 \%$ level of statistical significance. In 2010 , it is estimated that Credit Constraints reduce the likelihood the firm would invest by almost $48 \%$, again at a $1 \%$ level of statistical significance. Second, addressing the endogeneity of financial restrictions with respect to Investment is important, as we had expected. The simple probit estimations show a much weaker marginal effect of Credit Constraints on Investment decisions. In 2005 and 2010, they tell us that Credit Constraints would have reduced the likelihood that a firm invested by only $8 \%$ and $9 \%$, respectively. Third, the Wald-test of the bivariate probit model rejects the null of $\rho=0$ at the $1 \%$ significance level in both 2005 and 2010. It adds statistical evidence to what theoretical reasoning and the literature had already told us: financial constraints are endogenous with respect to Investment decisions. 
As robustness check, the bivariate probit models were also estimated using the profits of the establishment (sales minus total costs) instead of its simple sales (see footnote 12) again with shorter and longer different specifications of equation (2); the sales specifications are preferred because using profits implied losing around 100 observations. The results of the estimations using profits (not shown) yield estimates that are quantitatively very similar and highly statistically significant too, as expected. It strengthens the validity or the results.

Now, we have argued our IV can be deemed as true unexpected shocks to the firm cash flows. Lewbel and coauthors have, however, raised the valid concern that it is still the case that maximum likelihood estimation usually yields inconsistent estimates if any relevant IV is omitted. It calls for carrying out the analysis using their proposed "special regressor" method. As these scholars say (2012, p. 823; italics are mine) "Special regressor estimators can use any valid set of instruments, given only the standard linear instrumental variables assumptions." This standard assumption is that the IV affect the dependent variable only through the endogenous regressor, which in the context of our discussion is the case if our proposed instruments are in fact unexpected shocks to the firm's cash flows. Therefore, the only other thing we need for properly carrying out the special regressor method estimation is to have a regressor $\mathrm{V}$ satisfying the conditions which make it "special." These are that it is continuously distributed, it has large support, it is independent, and it is positively related with Investment. Fortunately for us, given the WBES information we could find at least one such regressor V: the variable Sales, which expresses the total amount of sales of the firm. That it is continuous and has large support can be seen with "eye-analysis," and that it is positively related with Investment was verified with regression analysis.

Thus, we carried out the estimations with the special regressor method, having Sales as the special regressor, Lostsales as IV for Credit Constraints in 2005, and Infpayments and Obstcrime as IV in 2010. Kernel density estimation was used, and the standard errors of the marginal effects of Credit Constraints on Investment were computed by bootstrapping. ${ }^{14}$ Table 4 presents the estimates of the marginal effects estimated. Intuitively, they are estimates of how much more likely is some firm does not invest in the unfortunate case it is credit constrained, as compared with the case in which it were not credit constrained, all else equal.

Table 4. "Special Regressor" Marginal Effects Estimations

\begin{tabular}{|l|c|c|}
\hline \multicolumn{3}{|l|}{ Dependent Variable: Investment } \\
\hline & $\mathbf{2 0 0 5}$ & $\mathbf{2 0 1 0}$ \\
\hline Marginal Effect of Credit & $-.18249^{* *}$ & $-.2093451^{*}$ \\
Constraints on Investment & $(.099959)$ & $(.1267494)$ \\
\hline Observations & 840 & 882 \\
\hline
\end{tabular}

Standard errors under parenthesis, ${ }^{*}, * *$, and ${ }^{* * *}$ denote statistical significance at the $10 \%$, $5 \%$, and $1 \%$ level, respectively.

As it is shown in Table 5, with the special regressor method estimation it is again found that financial restrictions have negatively affected Mexican firms Investment decisions. Both in 2005 and 2010 the marginal effects of Credit Constraints on Investment obtained are negative and highly statistically significant. In particular, for year 2005 it is estimated that Credit Constraints reduce the likelihood a firm invests in $18 \%$, with a $5 \%$ level of statistical significance. In turn, for year 2010 it is estimated that financial restrictions make less likely some firm invests by $21 \%$, with a $10 \%$ level of statistical significance.

\footnotetext{
${ }^{14}$ The "special regressor" estimation was implemented with Stata but it is not an official Stata command. It is a free contribution to the research community. The proper cite is: Baum, CF, 2012. sspecialreg: Stata module to estimate binary choice model with discrete endogenous regressor via special regressor method; http://ideas.repec.org/c/boc/bocode/s457546.html
} 
Thus, using special regressor methods we obtain further confirmation of the negative link between Credit Constraints and Investment decisions the bivariate probit had already suggested. In other words, the special regression method estimation in fact yields a "robustness check" to the "more standardly" used in the literature bivariate probit approach.

It is worth pointing out, however, that the special regressor method estimates are, from a quantitative point of view, smaller than the bivariate probit ones. Recalling, with the latter it was estimated that limited access to credit reduced the likelihood of investing by $47 \%$ in 2005 and by almost $48 \%$ in 2010. In contrast, with the special regressor method, it is estimated that financial restrictions reduce such likelihood by $18 \%$ in 2005 and by $21 \%$ in 2010 . These $18 \%$ and $21 \%$ effects are still certainly large, to be clear, but they are not as impressive as the $47 \%$ and $48 \%$ obtained earlier. This quantitative difference suggests the main strength of the findings of this paper is qualitative more than quantitative. In other words, it suggests that the strong finding of this contribution is that financial restrictions have been deterring Investment decisions, but we cannot establish by how much with that much confidence. It obviously opens a topic for future research.

\section{Concluding comments}

Mexico has gone through a transformative series of economic policy changes in the last three decades. The justification for each new policy was the pursuit of economic growth. The high expectations, however, have not been fulfilled. There are many factors that may have contributed to the slow- to no-growth outcome but among them limited access to credit has been pointed out as a very important one by scholars and policy-makers alike. Actually, there are two broad variants of the explanation for Mexico's slow growth. One, which is dominant, highlights the low total factor productivity of the country; Bolio et al. (2014), Tinoco-Zermeño et al. (2014), Hanson (2010), Kehoe and Ruhl (2010). The other, which is alternative, argues such low total factor productivity is more the consequence than the cause of the slow growth, and states the main reason behind Mexico's slow growth lies in a poor Investment rate; Moreno-Brid et al. (2005), Moreno-Brid and Ros (2009) and (2010), Ros (2013) and (2015). Whatever their larger disagreements, however, both sides of the debate agree Credit Constraints have played an important role: in the low productivity literature it is in turn partially explained by the financial restrictions faced by Mexican firms, and in the poor Investment rate one it is also partially explained by limited access to credit.

In this paper we focused on the role of Credit Constraints in limiting Investment. It turns out, however, that the negative influence of financial restrictions on firm's Investment decisions has not been firmly empirically established in the scholarly literature on Mexico. This paper presents the first attempt to empirically test this consensus (and rather intuitive) explanation of the low growth using firm-level, good quality data which is nationally representative and covers recent years. Two sorts of estimation analyses were carried out. First, the commonly found in the literature bivariate probit estimation. Second, the "special regressor" estimation method proposed by Lewbel and coauthors. It is less well-known but it addresses the problem of possible omitted IVs. In each analysis it was estimated that in fact Credit Constraints have been reducing physical capital accumulation of Mexican firms. Thus, I find it fair to say that the econometric analysis of this paper offers good evidence supporting the general thrust of scholars and policy-makers.

Policy implications may seem straightforward. It seems clear that improving access to finance for productive project is necessary in order to finally put Mexico on the path of high and sustained growth. In fact, in 2013-2014 reforms in more than 30 laws governing the credit system were introduced with the intended purpose of improving access to credit. Its results are still to be seen.

However, a proper discussion of the policy implications to be derived from the findings of this paper is very complex and calls for future research. The following three general 
comments highlight the care needed to translate policy implications gleaned from this research into genuinely helpful policy.

First, an insight offered in Moreno-Brid (2013) is worth keeping in mind. This scholar rightly points out that the simple conclusion "more should be lent" could be misleading. If carried out indiscriminately, more lending could be of little use. Lending must be carefully targeted and carefully administered. Furthermore, as shown in Skott and Gómez-Ramírez (2018), in the context of an economy with a significant informal sector like Mexico, easing access to finance for formal firms although would very likely increase their capital accumulation does not guarantee formal employment would grow too; supplementary policies may be needed to achieve the latter.

Second, the role of the State in improving the access to finance is a disputed topic. The dominant view is that the role of the State is to promote more competition -for example, in the highly concentrated Mexican banking system- and to improve the rule of law; indeed, the 2012-2014 reforms had this perspective in mind. However, other scholars have favored more state intervention, especially through national development banks; Levy (2007); Moreno-Brid (2013). In more general terms, we need to address not only the question of how much credit will be available and to which borrowers, but also on what terms credit will be available and from which lenders.

Third, easing Mexico's credit crunch will require working through multiple channels at once, not only those directly related to the financial system. Undergraduate level textbooks on economic development rightly stress that, in developing economies, solving one pressing issue is hard to be achieved if other issues are not addressed too; Todaro and Smith (2015). Indeed, the need to address several problems at once in order to act effectively on any one of them is one of the most important obstacles to getting out of "underdevelopment traps." In this respect, it should not be forgotten that appropriate measures to address poverty and inequality in contemporary Mexico should be an integral part of any sound policy package intending to ease the country's financial crunch. At the same time, easing Credit Constraints may make an important contribution to easing Mexico's distressing poverty and inequality burdens. In fact, influential international literature has argued that the presence of inefficient financial markets together with large inequality/poverty burdens is probably a very undesirable mix; Aghion et al. (1999), Benabou (1996), Bardhan et al. (2000), Galor and Zeira (1993). There is also more specific literature on contemporary Mexico which suggests that the credit crunch there has been positively related with its poverty burden; Niño-Zarazua (2013), Carreón et al. (2007), Bruhn and Love (2014).

\section{Referencias}

Aghion, P., Caroli, E., \& García-Peñalosa, C. (1999). Inequality and Economic Growth: the Perspective of the New Growth Theories. Journal of Economic Literature, 37(4), 1615-1660.

Aghion, P., Howitt, P., \& Mayer-Foulkes, D. (2005). The Effect of Financial Development on Convergence: Theory and Evidence. The Quarterly Journal of Economics. 120(1), 173-222.

Almeida, H., \& Campello, M. (2007). Financial Constraints, Asset Tangibility, and Corporate Investment. The Review of Financial Studies, 20(5), 1429-1460.

Angelucci, M. (2015). Migration and Financial Constraints: Evidence from Mexico. Review of Economics and Statistics, 97(1), 224-228.

Aroca, P., \& Malloney, W. (2005). Migration, Trade, and Foreign Direct Investment in Mexico. The World Bank Economic Review, 19(3), 449-472.

Banerjee, A. V., \& Duflo, E. (2014) Do Firms Want to Borrow More? Testing Credit Constraints Using a Directed Lending Program. The Review of Economic Studies, 81(2), 572-607. 
Bardhan, P., Bowles, S., \& Gintis, H. (2000). Wealth Inequality, Wealth Constraints, and Economic Performance. In A. B. Atkinson \& F. Bourguignon (Eds.), Handbook of Income Distribution (Vol. 1, pp. 541-604). Amsterdam ; New York: Elsevier.

Beck, T. \& Demirguc-Kunt, A. (2006) Small and medium-size enterprises: Access to finance as a growth constraint. Journal of Banking and Finance, 30(11), 2931-2943.

Beck, T. \& Demirguc-Kunt, A. (2008). Access to Finance: An Unfinished Agenda. The World Bank Economic Review, 22(3), 383-396.

Bergoeing, R., Kehoe, P. J., Kehoe, T. J., \& Soto, R. (2002). A Decade Lost and Found: Mexico and Chile in the 1980s. Review of Economic Dynamics, 5(1), 166-205.

Bénabou, R. (1996). Inequality and Growth. NBER Macroeconomics Annual, 11, 11-74.

Bigsten, A., Collier, P., Dercon, S., Fafchamps, M., Gauthier, B., Gunning, J. W., Oduro, A., Oostendorp, R., Patillo, C., \& Söderbom, M., Teal, F., \& Zeufack, A. (2003). Credit Constraints in Manufacturing Enterprises in Africa. Journal of African Economies, 12(1), 104-125,

Bolio, E., Remes, J., Lajous, T., Manyika, J., Rossé, M., \& Ramirez, E. (2014). A tale of two Mexicos: Growth and prosperity in a two-speed economy. McKinsey Global Institute.

Bruhn, M., \& Love, I. (2014). The Real Impact of Improved Access to Finance: Evidence from Mexico. The Journal of Finance, 69(3), 1347-1376.

Carreón, V. G., Di Giannatale, S., \& López, C. A. (2007). Mercados formal e informal de crédito en México: un estudio de caso. Documentos de Trabajo del CIDE 386.

Castañeda, G. (2003). Internal Capital Markets and Financing Choices of Mexican Firms, 1995-2000. In A. Galindo \& F. Schiantarelli (Eds.), Credit Constraints and Investment in Latin America (pp. 225-258). Washington D.C.: Inter-American Development Bank.

Chavarín Rodríguez, R. (2015). Morosidad en el pago de créditos y rentabilidad de la banca comercial en México. Revista Mexicana de Economía y Finanzas Nueva Época REMEF, 10(1), 71-83. DOI: https://doi.org/10.21919/remef.v10i1.67

Chodorow-Reich, G. (2014). The Employment Effects of Credit Market Disruptions: Firm-Level Evidence from the 2008-9 Financial Crisis. The Quarterly Journal of Economics, 129(1), 1-59.

Christofides, L. N., Stengos, T., \& Swidinsky, R. (1997). On the Calculation of Marginal Effects in the Bivariate Probit Model. Economics Letters, 54(3), 203-208.

Clavellina, J. L. (2013). Crédito bancario y crecimiento económico en México. Economía Informa, 378, 14-36.

Cotler, P., \& Woodruff, C. (2008). The impact of short-term credit on microenterprises: evidence from the Fincomun-Bimbo program in Mexico. Economic Development and Cultural Change, 56(4), 829-849.

de Souza, J.P. \& Gomez-Ramirez, L. (2018) The paradox of Mexico's export boom without growth: a demand-side explanation. Structural Change and Economic Dynamics. 47(December), 96-113.

Dong, Y., \& Lewbel, A. (2015). A Simple Estimator for Binary Choice Models with Endogenous Regressors. Econometric Reviews, 34(1-2), 85-105.

Evans, W. N., \& Schwab, R. M. (1995). Finishing High School and Starting College: Do Catholic Schools Make a Difference. The Quarterly Journal of Economics, 110(4), 941-974.

Fazzari, S., Hubbard, R., \& Petersen, B. (1988). Financing Constraints and Corporate Investment. Brookings Papers on Economic Activity, 1988(1), 141-206.

Galindo. A., Schiantarelli, F. \& Weiss, A. (2007). Does financial liberalization improve the allocation of Investment? Micro-evidence from developing countries. Journal of Development Economics, 83(2), $562-587$.

Galor, O., Zeira, J. (1993). Income Distribution and Macroeconomics. The Review of Economic Studies, $60(1), 35-52$,

Garrido, C., \& Prior, F. (2007). Bancarización y microfinanzas. Sistemas financieros para las Mypymen como un dilema central para el desarrollo económico en México. In J. L. Calva (Ed.), Financiamiento del crecimiento económico (pp. 57-77). México: Porrua - Universidad Nacional Autónoma de México.

Gelos, G., \& Werner, A. (2002). Financial Liberalization, Credit Constraints, and Collateral: Investment in the Mexican Manufacturing Sector. Journal of Economic Development, 67(1), 1-27.

Greene, W. H. (1996) Marginal Effects in the Bivariate Probit Model. NYU Working Paper EC-96-11.

Greene, W. H. (1998). Gender Economics Courses in Liberal Arts Colleges: Further Results. The Journal of Economic Education, 29(4), 291-300.

Greene, W. H. (2012). Econometric analysis (7th ed.). Boston: Prentice Hall.

Gorodnichenko, Y., \& Schnitzer, M. (2013). Financial Constraints and Innovation: Why Poor Countries Don't Catch Up. Journal of the European Economic Association, 11(5), 1115-1152.

Haber, S. H. (2005). Mexico's experiments with bank privatization and liberalization, 1991-2003. Journal of Banking and Finance, 29(8-9), 2325-2353.

Haber, S. H. (2009). Why Banks Do not Lend: The Mexican Financial System. In S. Levy E M. Walton (Eds.), No Growth without Equity? (pp. 283-317). Washington D.C.: The World Bank - Palgrave Macmillan.

Haber, S. H., Klein, H. S., Maurer, N., \& Middlebrook, K. J. (2008). Mexico since 1980. New York: Cambridge University Press. 
Haber, S. H., \& Mussachio, A. (2012). Foreign Entry and the Mexican Banking System, 1997-2007. Economía, 13(1), 13-37.

Hanson, G. H. (2010). Why isn't Mexico rich? Journal of Economic Literature, 48(4), 987-1004.

Hanson, G. H. (2012). Understanding Mexico's Economic Performance. Washington DC: Migration Policy Institute.

Harrison, A. E., \& McMillan, M. S. (2003). Does direct foreign Investment affect domestic Credit Constraints? Journal of International Economics, 61(1), 73-100.

Hericourt, J. \& Poncet, S. (2009). FDI and Credit Constraints: Firm-level evidence from China. Economic Systems, 33(1), 1-21.

Hu, X. \& Schiantarelli, F. (1998). Investment and Capital Market Imperfections: a Switching Regression Approach Using U.S. Firm Panel Data. The Review of Economics and Statistics, 80(3), 466-479.

Instituto Nacional de Estadística y Geografía (INEGI). (2004). Micro, pequeña, mediana y gran empresa. Estratificación de los establecimientos. Censos Económicos 2003. México: Instituto Nacional de Estadística y Geografía.

Instituto Nacional de Estadística y Geografía (INEGI). (2011). Micro, pequeña, mediana y gran empresa. Estratificación de los establecimientos. Censos Económicos 2009. México: Instituto Nacional de Estadística y Geografía.

Jaramillo, F., Schiantarelli, F., \& Weiss, A. (1996). Capital market imperfections before and after financial liberalization: An Euler equation approach to panel data for Ecuadorian firms. Journal of Development Economics, 51(2), 367-386.

Kaplan, S., \& Zingales, L. (1997). Do Investment-Cash Flow Sensitivities Provide Useful Measures of Financing Constraints? Quarterly Journal of Economics, 112(1), 169-215.

Kashyap, A. \& Stein, J. (2000). What Do a Million Observations on Banks Say about the Transmission of Monetary Policy? The American Economic Review, 90(3), 407-428.

Kehoe, T. J., \& Ruhl, K. J. (2010). Why have economic reforms in Mexico not generated growth? Journal of Economic Literature, 48(4), 1005-1027.

Khwaja, A., \& Mian, A. (2008). Tracing the Impact of Bank Liquidity Shocks: Evidence from an Emerging Market. The American Economic Review, 98(4), 1413-1442.

King, R. \& Levine, R. (1993). Finance and Growth: Schumpeter Might be Right. The Quarterly Journal of Economics, 108(3), 717-737.

Kuntchev, V., Ramalho, R., Rodríguez-Meza, J., \& Yang, J. S. (2013). What Have We Learned from the Enterprise Surveys Regarding Access to Credit by SMEs? World Bank Policy Research Working Paper 6670.

Lecuona, R. (2009). El financiamiento a las Pymes en México: la experiencia reciente. Economía, 6(17), 69-91.

Levy, N. (2007). Financiamiento del crecimiento y disponibilidad de créditos bancarios. In J. L. Calva (Ed.), Financiamiento del crecimiento económico (pp. 19-44). México: Porrúa - Universidad Nacional Autónoma de México.

Lewbel, A. (2000) Semiparametric qualitative response model estimation with unknown heteroscedasticity or instrumental variables. Journal of Econometrics, 97(1), 145-77.

Lewbel, A., Dong, Y., \& Yang, T. (2012). Comparing features of convenient estimators for binary choice models with endogenous regressor. The Canadian Journal of Economics, 45(3), 809-829.

Love, I., \& Sánchez, S. M. (2009). Credit Constraints and Investment Behavior in Mexico's Rural Economy. World Bank Policy Research Working Paper 5014.

Lustig, N. (2001). Life is not Easy: Mexico's Quest for Stability and Growth. Journal of Economic Perspectives, 15(1), 85-106.

Mántey de Anguiano, G. (2007). Política bancaria para el crecimiento con estabilidad. In J. L. Calva (Ed.), Financiamiento del crecimiento económico (pp. 45-56). México: Universidad Nacional Autónoma de México - Porrúa.

McKenzie, D., \& Woodruff, C. (2008). Experimental Evidence on Returns to Capital and Access to Finance in Mexico. The World Bank Economic Review, 22(3), 457-482.

Modigliani, F., \& Miller, M. (1958). The Cost of Capital, Corporation Finance and the Theory of Investment. The American Economic Review, 48(3), 261-297.

Moreno-Brid, J. C. (2013). Industrial Policy: A Missing Link in Mexico's Quest for Export-led Growth. Latin American Policy, 4(2), 216-237.

Moreno-Brid, J. C., Rivas, J. C., \& Santamaría, J. (2005). Industrialization and Economic Growth in Mexico After NAFTA: The Road Travelled. Development and Change, 36(6), 1095-1119.

Moreno-Brid, J. C., \& Ros, J. (2009). Development and growth in the Mexican economy : a historical perspective. Oxford - New York: Oxford University Press.

Moreno-Brid, J. C., \& Ros, J. (2010). La dimensión internacional de la economía mexicana. In S. Kuntz Fischer (Ed.), História económica general de México. De la Colonia a nuestros días (pp. 757-788). México: El Colegio de México - Secretaria de Economía.

Niño-Zarazua, M. (2013). Microcredit, Labor, and Poverty Impacts in Urban Mexico. Review of Development Economics, 17(4), 747-762. 
Ploetscher, C., \& Rottmann, H. (2002). Investment Behavior and Financing Constraints in German Manufacturing and Construction Firms. A Bivariate Ordered Probit Estimation. CESifo Economic Studies, 48(3), 383.

Ramírez, M. D. (1994). Public and Private Investment Behavior in Mexico, 1950-90: An Empirical Analysis. Southern Economic Journal, 61(1), 1-17.

Ros Bosch, J. (2013). Algunas tesis equivocadas sobre el estancamiento económico de México. México: El Colegio de México; Universidad Nacional Autónoma de México.

Ros Bosch, J. (2015). ¿Cómo salir de la trampa del lento crecimiento y alta desigualdad? México: El Colegio de México - Universidad Nacional Autónoma de México.

Sánchez, O. (2001). Investment by Manufacturing Firms and the Transmission of Monetary Policy in Mexico. Center for Research on Economic Development and Policy Reform Working Paper 111.

Savignac, F. (2008). The Impact of Financial Constraints on Innovation: What Can Be Learned from a Direct Measure? Economics of Innovation and New Technology, 17(6), 553-569.

Skott, P., \& Gómez-Ramírez, L. (2018). Credit Constraints and Economic Growth in a Dual Economy. Structural Change and Economic Dynamics. 45(June), 64-76.

Tinoco-Zermeño, M. Á., Venegas-Martínez, F., \& Torres-Preciado, V. H. (2014). Growth, bank credit, and inflation in Mexico: evidence from an ARDL-bounds testing approach. Latin American Economic Review, 23(1), 1-22.

Todaro, M., \& Smith, S. (2015). Economic Development (12th ed.). Pearson.

Villalpando, M. (2014). Bank Credit and Productivity: Evidence from Mexican Firms. Revista Mexicana de Economia y Finanzas Nueva Época REMEF, 9(2), 195-211. DOI: https://doi.org/10.21919/ remef.v9i2.62

Warman, F. \& Thirlwall, A.P., (1994). Interest rates, saving, Investment and growth in Mexico 1960-90: Tests of the financial liberalization hypothesis. The Journal of Development Studies, 94(3), 629-649.

Wooldridge, J. M. (2002). Econometric analysis of cross section and panel data. The MIT Press. 